• 研究简报・

\title{
浙江中南部近岸海域游泳动物功能群特征与多样性
}

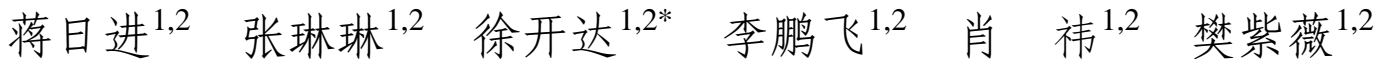 \\ 1 (浙江省海洋水产研究所, 农业部重点渔场渔业资源科学观测实验站, \\ 浙江省海洋渔业资源可持续利用技术研究重点实验室, 浙江舟山 316021) \\ 2 (浙江海洋大学海洋与渔业研究所, 浙江舟山 316021)
}

摘要: 为探明浙江中南部近岸海域游泳动物的群落结构和多样性, 作者于 2016 年春季进行了 2 个航次的底拖网调 查, 应用生物多样性指数、冗余分析对游泳动物功能群组成进行了研究。结果表明, 该海域166种游泳动物依据摄 食习性可分为 6 个功能群, 平均丰度百分比最高的为浮游动物/游泳动物食性功能群, 最低的为底栖动物食性功能 群; 平均生物量百分比最高的为浮游动物食性功能群, 最低的为碎屑食性功能群。相似性分析结果显示, 该海域游 泳动物的功能群结构在不同月份之间差异极显著。4月和 5 月的功能群多样性均值分别为 1.30 和 1.23 , 功能群多样性 指数与大个体种类(体质量 > $50 \mathrm{~g}$ )的总生物量呈极显著正相关, 功能群多样性与物种多样性呈正相关关系。几余 分析显示该海域游泳动物食性功能群受温度变化影响较大; 底栖动物食性功能群受水深变化影响较大。上述结果 表明, 浙江中南部海域游泳动物群落结构相对较稳定。

关键词: 浙江中南部; 游泳动物; 功能群; 生物多样性; 环境因子

\section{Characteristics and diversity of nekton functional groups in the coastal waters of south-central Zhejiang Province}

Rijin Jiang ${ }^{1,2}$, Linlin Zhang ${ }^{1,2}$, Kaida $\mathrm{Xu}^{1,2^{*}}$, Pengfei $\mathrm{Li}^{1,2}$, Yi Xiao ${ }^{1,2}$, Ziwei Fan ${ }^{1,2}$

1 Marine Fisheries Research Institute of Zhejiang Province, Key Research Station for Fisheries Resources of Main Fishing Ground, Ministry of Agriculture, Key Research Station of Sustainable Utilization for Marine Fisheries Resources, Zhoushan, Zhejiang 316021

2 Marine and Fisheries Research Institute, Zhejiang Ocean University, Zhoushan, Zhejiang 316021

\begin{abstract}
To understand the status of nekton communities and diversity in the coastal waters of south-central Zhejiang Province, we carried out two bottom trawl surveys in April and May of 2016. By using diversity index and redundancy analysis, we studied the composition of functional groups. We divided 166 species of nekton into six functional groups according to their feeding habits. The average abundance percentage of zooplanktivores/piscivores functional group was the highest while that of benthivores functional group was the lowest. Meanwhile, the average biomass percentage of zooplanktivores functional group was the highest while that of detritivorous functional group was the lowest. The results of ANOSIM showed a significant monthly difference between functional group structure of nekton communities in April and May, and the mean value of functional group diversity was 1.30 and 1.23 in those months, respectively. Functional group diversity of nekton communities was significantly positively correlated with the total biomass of large individual species (body mass $>50 \mathrm{~g}$ ), and functional group diversity was positively correlated with species diversity. Redundancy analysis showed that the piscivores functional group were greatly affected by temperature, while benthivores functional group was greatly affected by water depth. Through the analysis of functional group composition, we found the nekton community structure was stable in the coastal waters of south-central Zhejiang Province.
\end{abstract}

Key words: south-central Zhejiang Province; nekton; functional group; diversity; environmental factors

收稿日期: 2019-09-08; 接受日期: 2019-11-23

基金项目: 浙江省公益技术应用研究项目(LGN20C190012)、国家重点研发计划项目(2018YFD0900904; 2018YFD0900903)和浙江省重点研发计划项目 (2019C02056)

* 通讯作者 Author for correspondence. E-mail: xkd1981@163.com 
在生态系统中, 功能群是具有相似结构或功能 的不同物种的集合, 这些物种具有相似的生态作用 和较强的相互替代性。在海洋生态学研究中, 功能 群对外界环境的变化响应可作为推测生态系统健 康受损时种群压力指标的重要参考依据(Begon et al, 1996)。由于海洋生态系统的多样性和食物关系之间 的复杂性, 很难对系统内包含所有物种的食物网结 构进行定性和定量研究(张波等, 2007)。功能群可以 简化海洋生态系统食物网, 研究者可通过分析功能 群的生物量来探索其物质循环和能量流动(唐启升 等, 2005)。目前, 功能群作为一种研究方法已经被 广泛应用于河流、湖泊和海洋等生物群落结构分析 中(姜亚洲等, 2008)。

浙江中南部近岸海域岛屿众多, 受江浙沿岸 流、台湾暖流及西部沿岸河流冲淡水势力综合作用 的影响, 其水文环境适宜、基础饵料丰富, 众多海 洋生物在此栖息和繁殖, 是我国重要的天然渔场 (Lie \& Cho, 2002)。该海域鱼类主要以暖水性种类 为主(张洪亮等, 2013; 张琳琳等, 2019), 夏季在此 索饵育肥的小黄鱼(Larimichthys polyactis)和带鱼 (Trichiurus lepturus)为主要优势种(刘勇等, 2006; 戴黎斌等, 2018)。近年来, 由于气候变暖、涉海工 程建设和捕捞强度过大等因素的影响, 沿海整体生 态几余性下降(Micheli \& Halpern, 2005), 经济种类 性成熟提前, 平均营养级变小(程济生和朱金声, 1997; 盛福利等, 2009; 薛莹等, 2010), 浙江近岸海 域的渔业资源结构也遭到很大破坏。目前, 国内学 者对浙江中南部潮间带或岛礁等局部海域的生物 多样性(焦海峰等, 2011; 孙蓓蓓等, 2019)、群落结构 (赵永强等, 2009; 徐开达等, 2018)等方面开展了部 分研究。然而, 目前针对浙江中南部海域, 仅有岛 礁鱼类功能群的相关研究报道(胡成业等, 2016), 尚 无游泳动物功能群与环境因子相关性的研究报道。

游泳动物是海洋的高级消费者, 开展游泳动物 功能群研究是开展海洋生态系统修复工作的重要 基础(姜亚洲等, 2014)。海洋生态系统的结构稳定性 与游泳动物功能群的功能发挥有着直接的联系(刘 坤等, 2016)。为此, 本研究基于 2 个航次的定量采样, 探讨浙江中南部海域游泳动物功能群特征及其与 环境因子的相关性, 以期为该海域渔业资源的可持 续利用提供科学依据和数据支撑。

\section{材料与方法}

\section{1 数据来源}

依据《海洋调查规范 第6部分: 海洋生物调查》 (GB/T 12763.6-2007), 本研究于2016年春季(4月, 5 月) 在浙江中南部近岸海域 $\left(27^{\circ} 00^{\prime}-29^{\circ} 30^{\prime} \mathrm{N}\right.$, $120^{\circ} 45^{\prime}-123^{\circ} 30^{\prime}$ E) 50 个站位进行 2 个航次的底拖网 调查(图1)。调查船为主机功率 $202 \mathrm{~kW}$ 的有翼单囊底 拖网渔船, 每站位拖网约 $0.5 \mathrm{~h}$, 平均拖速 $3 \mathrm{kn}$, 囊 网网目为 $25 \mathrm{~mm}$, 网口周长 $50 \mathrm{~m}$ 。采用多功能水质 监测仪(JFE-AAQ171)同步调查各站位水深、温度、 盐度、溶解氧与浑浊度等环境数据。环境数据的分 析方法分别按照《海洋检测规范》GB17378.4-2007 和GB17378.5-2007的规定执行。采集的渔获物全部 冰鲜运回实验室, 参照《中国海洋生物名录》(刘瑞 玉, 2008)、《浙江海洋鱼类志》(赵盛龙等, 2016)进 行分类鉴定，统计尾数和体质量(精确到 $0.1 \mathrm{~g})$ 。

\section{2 数据处理}

\subsection{1 功能群划分}

根据游泳动物的摄食习性, 参考Garrison (2000)、Floeter等(2004)、张波等(2009)、庄平等(2010) 和吕振波等(2012), 将游泳动物划分为6类功能群: 浮游动物食性(zooplanktivores functional group,

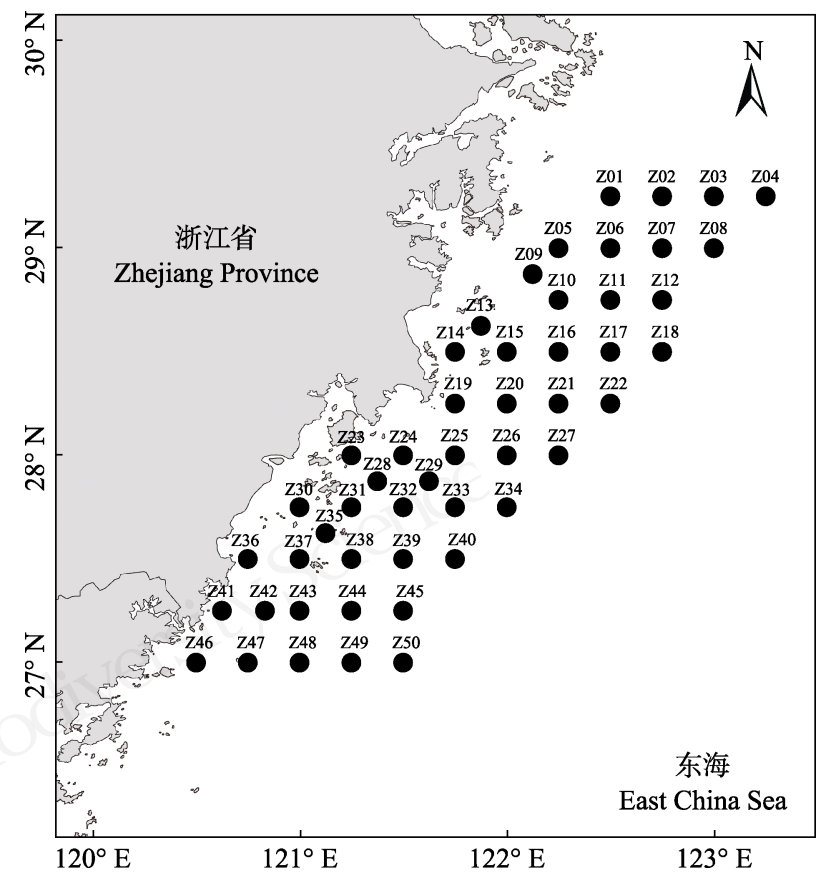

图1 浙江中南部近岸渔业资源调查站位

Fig. 1 The survey stations of fishery resource in the coastal waters of south-central Zhejiang Province 
FG1); 浮游动物/游泳动物食性(zooplanktivores/piscivores functional group, FG2); 游泳动物食性(piscivores functional group, FG3); 底栖动物食性(benthivores functional group, FG4); 碎屑食性(detritivores functional group, FG5); 杂食性(omnivores functional group, FG6)。

\subsection{2 多样性分析}

运用 Shannon-Wiener多样性指数 $\left(H^{\prime}\right)$ 对浙江中 南部海域游泳动物的功能群多样性和物种多样性 进行分析, 计算公式如下(钱迎倩和马克平, 1994):

$$
H^{\prime}=-\sum_{i=1}^{s} P_{i} \ln \left(P_{i}\right)
$$

式中, $S$ 为调查站位物种数 (或功能群个数), $P_{i}=$ $W_{i} / W, W_{i}$ 为第 $i$ 个物种 (或功能群)的生物量, $W$ 为该站 位的总生物量。

物种多样性是生物多样性最直接和最核心的 体现(魏辅文等, 2014), 功能群多样性对生态系统的 生产力有着较为显著的影响 (Lanta \& Lepš, 2006; Kong et al, 2011), 功能群多样性简化了群落结构研 究过程的复杂性, 且可操作性更强(Bai et al, 2001)。 为分析功能群多样性与物种多样性之间的关系, 将 功能群多样性作为因变量、物种多样性作为自变量 进行直线方程回归分析, 分析结果根据拟合优势度 $R^{2}$ 加以判断。此外, 将群落中大个体的物种(体质 量 > $50 \mathrm{~g}$ )的总生物量作为反映群落功能的重要指 标之一(Greenstreet \& Rogers, 2006; 姜亚洲等, 2014), 以体现群落提供高营养级层次物种的能力, 运用Pearson分别对物种多样性、功能群多样性与物 种的总生物量进行相关分析。利用相似性分析检验 (one-way analysis of similarity, ANOSIM)对该海域 春季(4月和5月)游泳动物群落的功能结构进行差异 显著性分析(Clarke, 1993)。

\subsection{3 冗余分析}

运用㝋余分析(redundancy analysis, RDA)对环 境因子和功能群的空间分布进行分析, 以揭示功能 群在该海域的空间分化状态。首先对物种数据进行 除趋势对应分析(detrended correspondence analysis, DCA), 根据每个轴梯度长度 (lengths of gradient, LGA)选择最佳排序方法。其中, 当 $L G A<3$ 时, 选择 圥余分析 (RDA); 当LGA > 4时, 选择典范对应分析 (canonical correspondence analysis, CCA); 当3 < LGA
$<4$ 时, 两者均可(Lepš \& Šmolauer, 2003)。根据DCA 分析结果, 本研究运用线性模型的RDA分析。

以上数据分析主要采用Primer 5.0、Canoco 5.0、 SPSS 17.0 等软件完成。

\section{结果}

\section{1 游泳动物功能群种类组成}

春季(4月和5月)共捕获游泳动物 166 种，隶属 于 20 目 83 科，其中鱼类 101 种，甲壳类52种，头足类 13种(附录1)。

浮游动物食性功能群包括赤鼻棱鳀(Thryssa kammalensis)和青鳞小沙丁鱼(Sardinella zunasi)等 28种，主要以桡足类、糠虾等浮游甲壳类为食，少 量摄食鱼类幼体，分布于水体上层。浮游动物/游泳 动物食性功能群包括蓝圆鲹(Decapterus maruadsi)、 凤鲚(Coilia mystus)等30个物种，主要摄食桡足类、 太平洋磷虾(Euphausia pacifica)、口虾蛄(Oratosquilla oratoria)幼体等浮游甲壳类和鳀(Engraulis japonicus)等小型鱼类，大部分属于中上层鱼类。游泳 动物食性功能群包括龙头鱼(Harpadon nehereus)、 花鲈(Lateolabrax maculatus)等23种，主要摄食七星 底灯鱼(Benthosema pterotum)、细条天答鲖 (Apogonichthys lineatus)等中小型鱼类，个体凶猛，游泳 速度快, 广泛栖息于各个水层。底栖动物食性功能 群包括宽体舌鳎(Cynoglossus robustus)、短蛸(Octopus ocellatus)等30种, 主要摄食小型蟹类、虾类等 底栖动物, 栖息于近海底层。碎屑食性功能群包括 细螯虾(Leptochela gracilis)、葛氏长臂虾(Palaemon gravieri)等31种，全部是小型虾蟹类，以腐烂破碎 的动植物残体为食, 栖息于底层水域。杂食性功能 群包括三疮梭子蟹(Portunus trituberculatus)、口虾 蛄等24种，以大型虾蟹类为主，摄食沙蚕、碎屑等 底栖生物，也能捕食小型鱼类、虾蟹类等游泳生物。

\section{2 游泳动物群落功能群结构}

ANOSIM结果表明：4月和5月间浙江中南部近 岸海域游泳动物群落的功能群结构差异极显著 $(R=$ $0.108, P<0.01)$ 。在2个航次调查中, 该海域游泳动物 的功能群组成状况见表1, 两个月平均丰度百分比最 高的为浮游动物/游泳动物食性, 其次为杂食性, 最 低为底栖动物食性; 平均生物量百分比最高的为浮 游动物食性, 其次为杂食性, 最低为碎屑食性。

4月和5月各功能群所含物种数不同(图2)。浮游 
动物/游泳动物食性功能群平均所含物种数最多 (7.24), 其次为杂食性功能群(5.38)和碎屑食性功能 群(5.36), 底栖动物功能群最少(3.35)。

\section{3 游泳动物群落功能群多样性}

4月和5月浙江中南部近岸海域游泳动物群落 的功能群多样性指数分别为 $1.30 \pm 0.29$ 和 $1.23 \pm$ 0.28 。方差分析表明: 该海域春季游泳动物功能群 多样性指数不存在显著的月份差异 $(F=0.103, P=$ 0.204)。对功能群多样性与物种多样性进行回归分 析, 利用直线方程、对数方程和指数方程进行曲线 拟合，结果表明，该海域二者间的直线方程拟合效 果最优(拟合优度 $R^{2}=0.7567$, 图3), 如果该海域游 泳动物的物种多样性降低, 其功能群多样性可能也 会随之下降。

Pearson相关分析结果显示: 浙江中南部近岸 海域游泳动物功能群多样性指数与群落中大个体 (体质量 > $50 \mathrm{~g}$ ) 生物的总生物量存在极显著的正相
关关系 $(F=0.310, P<0.01)$, 物种多样性指数与群 落中大个体(体质量 $>50 \mathrm{~g}$ )生物的总生物量也呈极 显著正相关关系 $(F=0.918, P<0.01)$ 。这表明该海 域游泳动物功能群多样性越高, 群落所能提供的大 个体生物的密度越大。

\section{4 游泳动物群落功能群与环境因子的相关性}

4月游泳动物功能群与环境因子的RDA分析结 果显示, 第一轴(特征值 $=0.30)$ 和第二轴(特征值 $=$ 0.07)表现出很高的物种一环境相关性, 功能群与环 境因子相关系数值分别为 0.86 和 0.69 。蒙特卡洛显 著性检验结果显示，第一排序轴和所有排序轴均呈 现极显著差异(第一轴: $F=1.40, P=0.001$; 所有轴: $F=3.20, P=0.001$ ) (图4a)。底层叶绿素和底层溶解 氧与第一排序轴呈正相关, 其中, 杂食性功能群受 浑浊度影响较大, 底栖动物食性功能群受底盐和水 深影响较大(表2)。

5 月游泳动物功能群与环境因子的RDA分析结

表1 浙江中南部近岸海域 4 月和 5 月游泳动物群落功能群的丰度百分比和生物量百分比

Table 1 Abundance percentage and biomass percentage of different nekton functional groups in the coastal waters of south-central Zhejiang Province during April and May

\begin{tabular}{|c|c|c|c|c|}
\hline \multirow[t]{2}{*}{$\begin{array}{l}\text { 功能群 } \\
\text { Functional group }\end{array}$} & \multicolumn{2}{|c|}{$\begin{array}{l}\text { 丰度百分比 } \\
\text { Abundance percentage (\%) }\end{array}$} & \multicolumn{2}{|c|}{$\begin{array}{l}\text { 生物量百分比 } \\
\text { Biomass percentage (\%) }\end{array}$} \\
\hline & 4月 April & 5月 May & 4月 April & 5月 May \\
\hline 浮游动物食性 Zooplanktivores functional group (FG1) & 8.36 & 10.83 & 6.43 & 12.02 \\
\hline 浮游动物/游泳动物食性 Zooplanktivores /Piscivores functional group (FG2) & 33.19 & 61.23 & 17.13 & 25.09 \\
\hline 游泳动物食性 Piscivores functional group (FG3) & 7.11 & 7.73 & 27.55 & 30.74 \\
\hline 底栖动物食性 Benthivores functional group (FG4) & 1.89 & 1.00 & 9.17 & 8.87 \\
\hline 碎屑食性 Detritivores functional group (FG5) & 15.22 & 7.63 & 4.60 & 3.76 \\
\hline 杂食性 Omnivores functional group (FG6) & 34.22 & 11.58 & 35.12 & 19.52 \\
\hline
\end{tabular}

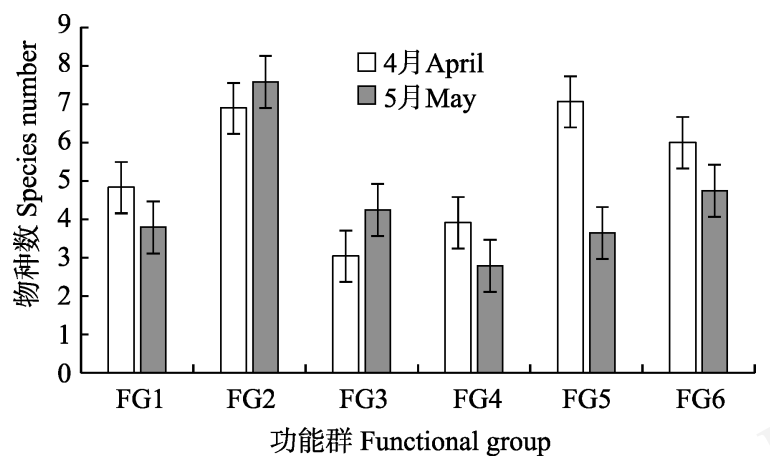

图24月和5月浙江中南部近岸海域游泳动物群落各功能群 所含物种数。功能群代号同表1。

Fig. 2 Species number of each nekton functional group in the coastal waters of south-central Zhejiang Province during April and May. Functional group codes are the same as in Table 1.

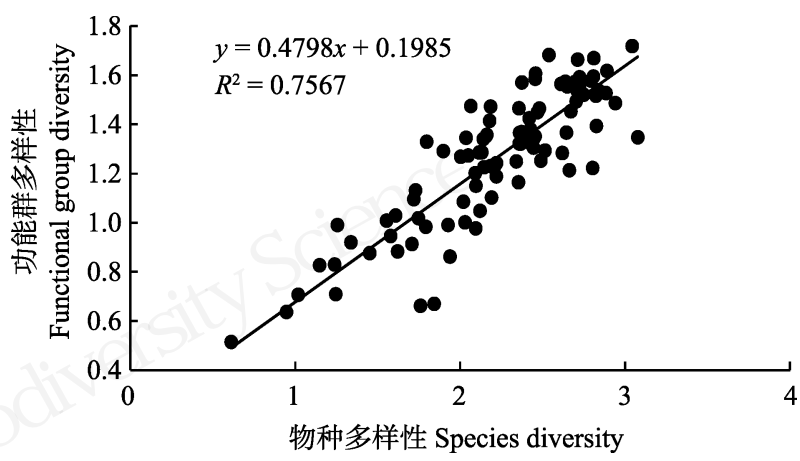

图3 浙江中南部近岸海域游泳动物群落物种多样性与功能 群多样性的线性关系

Fig. 3 The linear relationship between species diversity and functional diversity for the nekton community in the coastal waters of south-central Zhejiang Province 

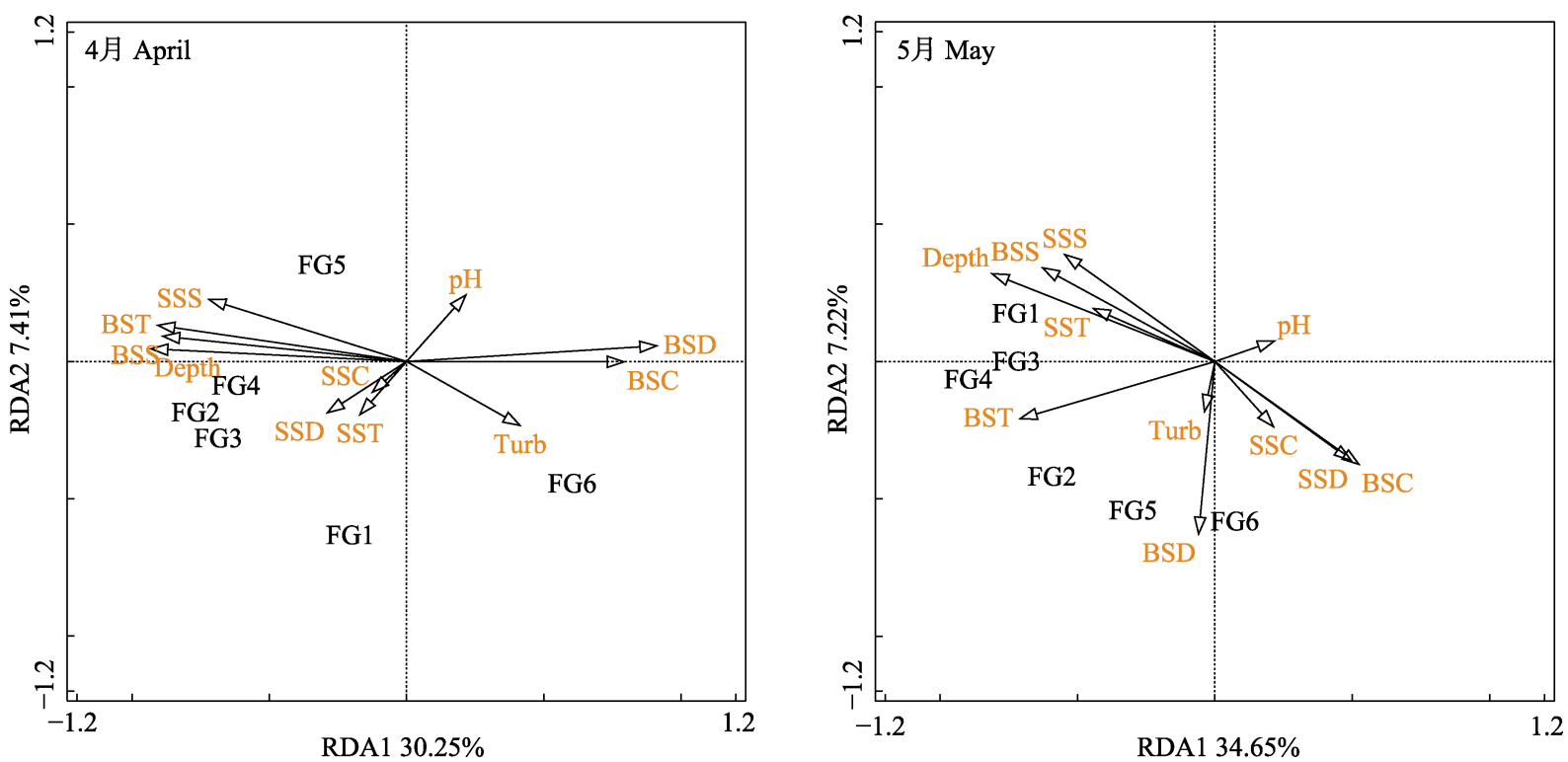

图4 4月和5月浙江中南部近岸海域游泳动物功能群与环境因子的RDA排序图。SST: 表层温度; SSS: 表层盐度; SSC: 表层 叶绿素; SSD: 表层溶解氧; BST: 底层温度: BSS: 底层盐度; BSC: 底层叶绿素; BSD: 底层溶解氧; pH: 酸碱度; Turb: 浑 浊度; Depth: 水深。功能群代号同表1。

Fig. 4 Redundancy analysis ordination diagrams for nekton functional groups and environmental factors in the coastal waters of south-central Zhejiang Province during April and May. SST, Surface temperature; SSS, Surface salinity; SSC, Surface chlorophyll; SSD, Surface dissolved oxygen; BST, Bottom temperature; BSS, Bottom salinity; BSC, Bottom chlorophyll; BSD, Bottom dissolved oxygen; Turb, Turbidity; Depth, Depth of water. Functional group codes are the same as in Table 1.

表2 4月和5月浙江中南部近岸海域游泳动物功能群与环境因子的RDA分析结果

Table 2 Results of redundancy analysis of nekton functional groups and environmental factors in the coastal waters of south-central Zhejiang Province during April and May

\begin{tabular}{lllll}
\hline 环境参数 & 4月 April & & 5月 May \\
\cline { 2 - 3 } \cline { 3 - 5 } Environmental variables & RDA1 (30.25\%) & RDA2 (7.41\%) & RDA1 (34.65\%) & RDA2 (7.22\% ) \\
\hline 表层温度 Surface temperature (SST) & -0.15 & -0.13 & -0.40 & 0.12 \\
表层盐度 Surface salinity (SSS) & -0.62 & 0.16 & -0.49 & 0.24 \\
表层叶绿素 Surface chlorophyll (SSC) & -0.11 & -0.08 & 0.19 & -0.15 \\
表层溶解氧 Surface dissolved oxygen (SSD) & -0.25 & -0.13 & 0.45 & -0.22 \\
底层温度 Bottom temperature (BST) & -0.78 & 0.09 & -0.64 & -0.13 \\
底层盐度 Bottom salinity (BSS) & -0.76 & 0.06 & -0.56 & 0.21 \\
底层叶绿素 Bottom chlorophyll (BSC) & 0.68 & 0.00 & 0.47 & -0.23 \\
底层溶解氧 Bottom dissolved oxygen (BSD) & 0.78 & 0.04 & -0.05 & -0.38 \\
pH & 0.19 & 0.17 & 0.20 & 0.05 \\
浑浊度 Turbidity (Turb) & 0.36 & -0.16 & -0.03 & -0.11 \\
水深 Depth of water (Depth) & -0.80 & 0.03 & -0.73 & 0.20 \\
\hline
\end{tabular}

果显示, 第一轴(特征值 $=0.35)$ 和第二轴(特征值 $=$ 0.07)表现出很高的物种-环境相关性, 功能群与环 境因子相关系数分别为 0.90 和 0.61 。蒙特卡洛显著 性检验结果显示, 第一排序轴和所有排序轴均呈现 极显著差异(第一轴: $F=1.70, P=0.001$; 所有轴: $F$ $=3.60, P=0.001)($ 图 $4 \mathrm{~b})$ 。底层叶绿素和表层溶解氧 与第一排序轴呈较大正相关, 其中杂食性功能群受 底层溶解氧影响较大, 浮游动物/游泳动物食性功
能群和底栖动物食性功能群受底层温度影响较大, 游泳动物食性功能群受水深影响较大(表2)。

\section{3 讨论}

\section{1 浙江中南部游泳动物群落功能群组成特征分析}

浙江中南部海域地处亚热带, 气候变化受气 旋、冷空气和台风3个主要天气系统的控制，冬夏季 风交替影响该海域的水系、水温等。各游泳动物功 
能群受水文条件月变化的影响明显，调查站位5月 的平均水温高于 4 月, 春季随着水温升高, 带鱼、小 黄鱼和银鲳(Pampus argenteus)等许多游泳生物洄 游至浙江近岸产卵索饵(邓景耀和赵传絪, 1991), 洄 游时间的不同导致了不同月份功能群组成的差异 变化。此外, 4月和 5 月浮游动物/游泳动物食性、游 泳动物食性和杂食性功能群的丰度和生物量百分 比均大于 $74.50 \%$, 这与东海北部研究结果相似(姜 亚洲等, 2008)。

通过划分功能群有助于理解生物多样性与生 态系统的结构和功能之间的相互关系, 可简化海洋 生态系统的食物网及其能量流动的研究(Arenas et $\mathrm{al}$, 2006)。基于浙江中南部海域的游泳动物功能群 组成, 大致可以将它们的食物关系归纳为以下几条 食物链: (1)浮游植物 $\rightarrow$ 浮游动物 $\rightarrow$ 浮游动物食性功 能群 $\rightarrow$ 浮游动物/游泳动物食性功能群(或游泳动物 食性功能群), 如: 库氏圆䇥藻(Coscinodiscus kuetzi$n g$ ii) $\rightarrow$ 太平洋磷虾 $\rightarrow$ 七星底灯鱼 $\rightarrow$ 蓝圆鲐(或带鱼); (2)有机碎屑 $\rightarrow$ 底栖动物 $\rightarrow$ 底栖食性功能群(或杂食 性功能群), 如: 有机碎屑 $\rightarrow$ 贝类或沙蚕 $\rightarrow$ 宽体舌鳎 (或三疮梭子蟹); (3)有机碎屑 $\rightarrow$ 碎屑食性功能群 $\rightarrow$ 游泳动物食性功能群(或杂食性功能群), 如: 碎屑 $\rightarrow$ 细巧仿对虾 (Parapenaeopsis tenella) $\rightarrow$ 黄姑鱼 (Nibea albiflora)(或日本蟳 Charybdis japonica)。据 统计, 浙江中南部海域浮游动物有 600 多种, 游泳 生物超过1,000种, 通过功能群分析可以将该海域 的食物网结构简化为上述几条主要的能量和物质 流动途径。在潮间带食物网中, 浮游动物食性功能 群和碎屑食性功能群的种类和数量的减少, 会在一 定程度上影响大型底栖动物的群落结构稳定性及 营养元素流通(Thrush et al, 2006)。本研究中浮游动 物功能群和碎屑食性功能群是食物网中的关键种 群, 其生物量的高低决定了高营养级的游泳动物功 能群和杂食性功能群的多寡, 也直接影响了该海域 的重要经济种类渔业产量。

\section{2 浙江中南部游泳动物群落功能群多样性与年 余性分析}

功能群多样性指数反映了群落中不同功能群 的物种数和均匀度 (马文静等, 2013)。不同功能群中 功能相似的物种越多, 在面对环境变化时物种存活 的几率也就越大, 有利于维持生态系统的稳定性 (Shan et al, 2011)。本研究发现, 浙江中南部近岸海
域游泳动物群落的功能群多样性指数(1.23-1.30)高 于东海北部近海(姜亚洲等, 2008), 推测是由于调查 时间不同导致的, 通常近海春季的游泳生物种类组 成和生物量高于冬季, 而姜亚洲等(2008)研究的季 节在冬季。该海域游泳动物群落功能群多样性与群 落大个体物种(体质量 > $50 \mathrm{~g}$ )的总生物量呈正相 关。大个体物种营养级通常较高, 其资源密度可反 映群落提供高营养级种类的能力和该水域渔业资 源开发的潜力(Bellwood et al, 2003; Woodward et al, 2005)。因此, 加强该海域游泳动物群落功能群的保 护具有重要的现实意义，既可保障该海域渔获物的 资源产量, 又有利于群落功能的正常运转。

浙江中南部近岸海域游泳动物群落物种多样 性与功能群多样性呈正相关关系, 这表明随着该海 域物种多样性的降低, 其功能群多样性也随之下 降。姜亚洲等 $(2008,2014)$ 认为象山港海域比东海北 部的物种午余程度大，同等幅度物种多样性的丧失 会引起该海域的功能群多样性的降低。浙江中南部 海域的物种多样性与功能群多样性拟合直线方程 的斜率与象山港海域的斜率相当，这表明该海域与 象山港有相似的生态压力。本研究发现, 调查海域 生态系统内游泳动物食性功能群虽然所包含种类 数最少, 但是物种营养级非常高, 对控制物质循环 和能量流动起着关键的作用, 部分重要种类的减少 可能会导致功能群多样性的丧失。目前海域内龙头 鱼所占的资源量最大(张洪亮等, 2013)，随着带鱼等 高营养级资源的衰退，龙头鱼承受着较大捕捞压力, 若其资源量持续下降, 游泳动物食性功能群的生物 量也将锐减, 进而对该功能群营养结构产生较为严 重的影响。因此, 在浙江沿岸产卵场保护区的管理 过程中，应对高营养级的种类进行资源保护和合理 利用, 以维持游泳动物群落功能群的多样性, 确保 该海域生态系统的稳定。

\section{3 浙江中南部游泳动物群落功能群与环境因子} 的相关性分析

海洋环境因子对游泳动物功能群的分布会产 生不同的影响，环境异质性大的生态系统中的功能 群数量一般多于环境差异小且稳定的系统(Poff \& Allan,1995)。其中, 温度和盐度是影响游泳动物生 存最为重要的环境因子, 影响其生理过程、分布及 生物资源量，同时会引起水体中诸如溶解氧、 $\mathrm{pH}$ 值、饵料生物资源等其他因子的变化(龙华, 2005)。 
溶解氧通过生理耐受限度影响其活动空间和栖息 地的改变, 最终影响游泳动物的群落分布。悬浮物 高则会降低水体中透明度, 不利于浮游植物的光合 作用, 进而会影响浮游动物及以其为饵料的生物的 分布(李冠国和范振刚, 2011)。水深和底质粒径会影 响大型底栖动物各功能群的空间分布(Dolbeth et al, 2009),

本研究冗余分析表明, 温度、盐度、溶解氧和 水深是影响游泳动物功能群分布的主要环境因子。 杂食性功能群受浑浊度和底层溶解氧浓度影响较 大, 该功能群以虾蟹类等底层游泳动物为主, 底层 溶解氧浓度影响其生理生态, 高浑浊度的海域往往 含有很多的有机碎屑, 而杂食性功能群物种以这些 有机碎屑为食。底栖动物食性功能群主要包括栖息 在水体底部的舌鳎、小型蟹类等水生动物群落, 受 底层盐度、底层温度和水深影响较大(刘坤等, 2016)。 浮游动物食性功能群和游泳动物食性功能群(FG3) 受水深影响大, 两个功能群中都包含有上层物种和 底层物种, 游泳动物栖息于不同水层, 因此受到不 同水深梯度的影响。上述结果表明, 不同类型的功 能群表现出不同的环境相关性。

游泳生物的摄食生态是复杂变化着的，在不同 的发育阶段其食性差异很大，一般幼体以浮游动物 或小型鱼类等为食, 成体摄食大个体的饵料生物 (蒋日进等, 2011)。另外, 游泳生物很少摄食某一种 甚至某一类食物，除非在贻贝筏式养殖区或洞穴等 较稳定的生态系统中(王凯等, 2014)。在浙江中南部 这种开阔且环境变化大的海域, 将游泳生物划分为 6 个功能群显然无法完全揭示该海域生态系统的食 物关系和食物网结构, 仍需要结合粒径谱或质量谱 等生态学方法来开展相关研究。

致谢: 本研究工作得到了浙江省海洋水产研究所渔 业资源与生态研究室张洪亮、陈峰、李振华、卢占 晖、戴乾、李德伟、王好学等老师在调查和样品分 析等方面的大力协助，特表谢忱!

\section{参考文献}

Arenas F, Iñigo S, Jenkins HSR (2006) The invasibility of marine algal assemblages: Role of functional diversity and identity. Ecology, 87, 2851-2861.

Bai YF, Li LH, Huang JH, Chen ZZ (2001) The influence of plant diversity and functional composition on ecosystem stability of four Stipa communities in the Inner Mongolia Plateau. Acta Botanica Sinica, 43, 280-287.

Begon M, Harper JL, Towsend CR (1996) Ecology: Individuals, Populations and Communities. Blackwell Scientific, Victoria (Australia).

Bellwood DR, Hoey A, Choat JH (2003) Limited functional redundancy in high diversity systems: Resilience and ecosystem function on coral reefs. Ecology Letters, 6, 281-285.

Cheng JS, Zhu JS (1997) Study on feeding characteristics and nutrient level of main economic invertebrates in the Yellow Sea. Acta Oceanologica Sinica, 19(6), 102-108. (in Chinese with English abstract) [程济生, 朱金声 (1997) 黄海主要 经济无脊椎动物摄食特征及其营养层次的研究. 海洋学 报, 19(6), 102-108.]

Clarke KR (1993) Non-parametric multivariate analyses of changes in community structure. Australian Journal of Ecology, 18, 117-143.

Dai LB, Tian SQ, Peng X, Gao CX, Ye S, Du XX, Liu P (2018) Distribution of Larimichthys polyactis and its relationship with environmental factors in offshore water of southern Zhejiang. Chinese Journal of Applied Ecology, 29, 1352-1358. (in Chinese with English abstract) [戴黎斌, 田思泉, 彭欣, 高春霞, 叶深, 杜晓雪, 刘攀 (2018) 浙江南部近海小黄 鱼资源分布及其与环境因子的关系. 应用生态学报，29, 1352-1358.]

Deng JY, Zhao CY (1991) Marine Fishery Biology. China Agriculture Press, Beijing. (in Chinese) [邓景耀, 赵传絪 (1991) 海洋渔业生物学. 中国农业出版社, 北京.]

Dolbeth M, Teixeira H, Marques JC, Pardal MÂ (2009) Feeding guild composition of a macrobenthic subtidal community along a depth gradient. Scientia Marina, 73, 225-237.

Floeter SR, Ferreira CEL, Dominici-Arosemena A, Zalmon IR (2004) Latitudinal gradients in Atlantic reef fish communities: Trophic structure and spatial use patterns. Journal of Fish Biology, 64, 1680-1699.

Garrison LP (2000) Spatial and dietary overlap in the Georges Bank ground fish community. Canadian Journal of Fishery and Aquatic Sciences, 57, 1679-1691.

Greenstreet SPR, Rogers S (2006) Indicators of the health of the North Sea fish community: Identifying reference levels for an ecosystem approach to management. ICES Journal of Marine Science, 63, 573-593.

Hu CY, Shui YY, Tian K, Li L, Qin HL, Zhang CC, Ji MM, Shui BN (2016) Functional group classification and niche identification of major fish species in the Qixing Islands Marine Reserve, Zhejiang Province. Biodiversity Science, 24, 175-184. (in Chinese with English abstract) [胡成业, 水玉跃, 田阔, 李良, 覃胡林, 张春草, 冀萌萌, 水柏年 (2016) 浙江七星列岛海洋特别保护区主要鱼类功能群划 分及生态位分析. 生物多样性, 24, 175-184.]

Jiang RJ, Xu HX, Jin HW, Zhou YD, He ZT (2012) Feeding habits of blue mackerel scad Decapterus maruadsi Temminck 
et Schlegel in the East China Sea. Journal of Fisheries of China, 36, 216-227. (in Chinese with English abstract) [蒋 日进, 徐汉祥, 金海卫, 周永东 贺舟挺 (2012) 东海蓝 圆鰺的摄食习性研究. 水产学报, 36, 216-227.]

Jiang YZ, Cheng JH, Li SF (2008) Variation in fish community structure and biodiversity in the north of the East China Sea between two periods. Journal of Fishery Sciences of China, 15, 453-459. (in Chinese with English abstract) [姜亚洲, 程家华, 李圣法 (2008) 东海北部鱼类群落多样性及其 结构特征的变化. 中国水产科学, 15, 453-459.]

Jiang YZ, Lin N, Yuan XW, Jiao HF, Li SF (2014) Functional group composition and functional diversity of nekton community in the Xiangshan Bay. Oceanologia et Limnologia Sinica, 45, 108-114. (in Chinese with English abstract) [姜 亚洲, 林楠, 袁兴伟, 焦海峰, 李圣法 (2014) 象山港游 泳动物群落功能群组成与功能群多样性. 海洋与湖沼, 45, 108-114.]

Jiao HF, Peng XM, You ZJ, Shi HX, Lou ZJ, Liu HD (2011) Species diversity of macrobenthos in the rocky intertidal zone of Yushan Island. Biodiversity Science, 19, 511-518. (in Chinese with English abstract) [焦海峰, 彭小明, 尤仲 杰, 施慧雄, 楼志军, 刘红丹 (2011) 渔山岛岩石相潮间 带大型底栖动物物种多样性. 生物多样性, 19, 511-518.]

Kong DL, Wu HF, Zeng H, Lü XT, Simmons M, Wang M, Sun XF, Han XG (2011) Plant functional group removal alters root biomass and nutrient cycling in a typical steppe in Inner Mongolia, China. Plant and Soil, 346, 133-144.

Lanta V, Lepš J (2006) Effect of functional group richness and species richness in manipulated productivity-diversity studies: A glasshouse pot experiment. Acta Oecologica, 29, 85-96.

Lepš J, Šmolauer P (2003) Multivariate Analysis of Ecological Data Using CANOCO. Cambridge University Press, New York.

Li GG, Fan ZG (2011) Marine Ecology. Higher Education Press, Beijing. (in Chinese) [李冠国, 范振刚 (2011) 海洋 生态学. 高等教育出版社, 北京.]

Lie HJ, Cho CH (2002) Recent advances in understanding the circulation and hydrography of the East China Sea. Fisheries Oceanography, 11, 318-328.

Lin LS, Yan LP, Ling JZ, Liu Y, Zhou RK (2005) Food habits of hairtail in the East China Sea region. Marine Fisheries, 27, 187-192. (in Chinese with English abstract) [林龙山, 严利平, 凌建忠, 刘勇, 周荣康 (2005) 东海带鱼摄食习 性的研究. 海洋渔业, 27, 187-192.]

Liu K, Lin HS, He XB, Huang YQ, Lin JH, Mou JF, Zhang SY, Wang JJ (2016) Functional feeding group of macrozoobenthos and their relationships to environmental factors in Xiamen coastal waters. Acta Oceanologica Sinica, 38, 95-105. (in Chinese with English abstract) [刘坤, 林和山, 何雪宝, 黄雅琴, 林俊辉, 牟剑锋, 张舒怡, 王建军 (2016) 厦门近岸海域大型底栖动物摄食功能群及其与环 境因子的关系. 海洋学报, 38, 95-105.]

Liu RY (2008) Checklist of Marine Biota of China Sea. Scie- nce Press, Beijing. (in Chinese) [刘瑞玉 (2008) 中国海洋 生物名录. 科学出版社, 北京.]

Liu Y, Li SF, Cheng JH (2006) A study on seasonal changes of the fish communities in the East China Sea and the Huanghai Sea. Acta Oceanologica Sinica, 28(4), 108-114. (in Chinese with English abstract) [刘勇, 李圣法, 程家骅 (2006) 东 海、黄海鱼类群落结构的季节变化研究. 海洋学报, 28(4), 108-114.]

Long H (2005) The effect of temperature on fish survival. Fishery Modernization, 32(2), 20-22. (in Chinese with English abstract) [龙华 (2005) 温度对鱼类生存的影响. 渔业现 代化, 32(2), 20-22.]

Lü ZB, Li F, Xu BQ, Wang B (2012) Fish community diversity during spring and autumn in the Yellow Sea off the coast of Shandong. Biodiversity Science, 20, 207-214. (in Chinese with English abstract) [吕振波, 李凡, 徐炳庆, 王波 (2012) 黄海山东海域春、秋季鱼类群落多样性. 生物多 样性, 20, 207-214.]

Ma WJ, Zhang Q, Niu JM, Kang S, Liu PT, He X, Yang Y, Zhang YN, Wu JG (2013) Relationship of ecosystem primary productivity to species diversity and functional group diversity: Evidence from Stipa breviflora grassland in Nei Mongol. Chinese Journal of Plant Ecology, 37, 620-630. (in Chinese with English abstract) [马文静, 张庆, 牛建明, 康 萨如拉, 刘朋涛, 何欣, 杨艳, 张艳楠, 邬建国 (2013) 物种多样性和功能群多样性与生态系统生产力的关系 - 以内蒙古短花针茅草原为例. 植物生态学报, 37 , 620-630.]

Micheli F, Halpern BS (2005) Low functional redundancy in coastal marine assemblages. Ecology Letters, 8, 391-400.

Poff NL, Allan JD (1995) Functional organization of stream fish assemblages in relation to hydrological variability. Ecology, 76, 606-627.

Qian YQ, Ma KP (1994) Principle and Method of Biodiversity Studies. China Science and Technology Press, Beijing. (in Chinese) [钱迎倩, 马克平 (1994) 生物多样性研究的原 理与方法. 中国科学技术出版社, 北京.]

Shan XJ, Jin XS, Zhou ZP, Dai FQ (2011) Fish community diversity in the middle continental shelf of the East China Sea. Chinese Journal of Oceanology and Limnology, 29, 1199-1208.

Sheng FL, Zeng XQ, Xue Y (2009) Study on propagation and feeding habits of Oratosquilla oratoria in the inshore waters of Qingdao. Periodical of Ocean University of China, 39, 326-332. (in Chinese with English abstract) [盛福利, 曾晓 起, 薛䒯 (2009) 青岛近海口虾蛄的繁殖及摄食习性研 究. 中国海洋大学学报(自然科学版), 39, 326-332.]

Sun BB, Yu CG, Liu H, Yan WC, Zhang WJ, Dai DX (2019) Spring and autumn shrimp and crab biodiversity in the east Nanji Islands. Biodiversity Science, 27, 787-795. (in Chinese with English abstract) [孙蓓蓓, 俞存根, 刘惠, 颜文超, 张 文俊, 戴冬旭 (2019) 南鹿列岛东侧海域春秋季虾蟹类 生物多样性. 生物多样性, 27, 787-795.] 
Tang QS, Su JL, Zhang J (2005) Key processes and sustainable mechanisms of ecosystem food production in the coastal ocean of China. Advance in Earth Sciences, 20, 1280-1287. (in Chinese with English abstract) [唐启升, 苏纪兰, 张经 (2005) 我国近海生态系统食物产出的关键过程及其可持 续机理. 地球科学进展, 20, 1280-1287.]

Thrush SF, Hewitt JE, Gibbs M, Lundquist G, Norkko A (2006) Functional role of large organisms in intertidal communities: Community effects and ecosystem function. Ecosystem, 9, 1029-1040.

Wang K, Zhang SY, Wang ZH, Zhao J, Jiang RJ (2014) Dietary composition and feeding strategy of Agrammus agrammus off the Ma'an Archipelago Special Marine Reserves. Journal of Shanghai Ocean University, 23, 251-257. (in Chinese with English abstract) [王凯, 章守宇, 汪振华, 赵 静, 蒋日进 (2014) 马鞍列岛海洋特别保护区斑头六线 鱼的摄食习性. 上海海洋大学学报, 23, 251-257.]

Wei FW, Nie YG, Miao HX, Lu H, Hu YB (2014) Advancements of the researches on biodiversity loss mechanisms. Chinese Science Bulletin, 59, 430-437. (in Chinese with English abstract) [魏辅文, 聂永刚, 苗海霞, 路浩, 胡义波 (2014) 生物多样性丧失机制研究进展. 科学通报, 59, 430-437.]

Woodward G, Ebenman B, Emmerson M, Montoya JM, Olesen JM, Valido A, Warren PH (2005) Body size in ecological networks. Trends in Ecology \& Evolution, 20, 402-409.

Xu KD, Lu KE, Lu ZH, Dai Q (2018) Ecological niche analysis of dominant shrimp species in the Jiushan Islands Marine Nature Reserve. Biodiversity Science, 26, 601-610. (in Chinese with English abstract) [徐开达, 卢衍尔, 卢占晖, 戴乾 (2018) 韭山列岛自然保护区虾类优势种生态位. 生物多样性, 26, 601-610.]

Xue Y, Xu BD, Gao TX, Xu H, Lin LS (2010) Preliminary study on the feeding habit of Lophius litulon during autumn in the North Yellow Sea. Periodical of Ocean University of China, 40, 39-44. (in Chinese with English abstract) [薛芗, 徐宾铎, 高天翔, 徐浩, 林龙山 (2010) 北黄海秋季黄鮟 鱇摄食习性的初步研究. 中国海洋大学学报(自然科学 版), 40, 39-44.]

Zhang B, Jin XS, Tang QS (2009) Functional groups of high trophic level communities in adjacent waters of Changjiang estuary. Chinese Journal of Applied Ecology, 20, 344-351. (in Chinese with English abstract) [张波, 金显仕, 唐启升 (2009) 长江口及邻近海域高营养层次生物群落功能群及 其变化. 应用生态学报, 20, 344-351.]

Zhang B, Tang QS, Jin XS (2007) Functional groups of fish assemblages and their major species at high trophic level in the East China Sea. Journal of Fishery Sciences of China, 14, 939-949. (in Chinese with English abstract) [张波, 唐 启升, 金显仕 (2007) 东海高营养层次鱼类功能群及其 主要种类. 中国水产科学, 14, 939-949.]

Zhang HL, Song ZQ, Pan GL, Chen F, Zhou YD (2013) Diversity analysis of fish in the coastal area of Zhejiang during spring. Oceanologia et Limnologia Sinica, 44, 126-134. (in Chinese with English abstract) [张洪亮, 宋之琦, 潘国良, 陈峰, 周永东 (2013) 浙江南部近海春季鱼类多样性分 析. 海洋与湖沼, 44, 126-134.]

Zhang LL, Jiang RJ, Yin R, Xu KD, Fang F, Xu YP, Ke AY (2019) Spatial niche and differentiation of major nekton species in Yueqing Bay, Zhejiang, China. Chinese Journal of Applied Ecology, 30, 3911-3920. (in Chinese with English abstract) [张琳琳, 蒋日进, 印瑞, 徐开达, 方芳, 徐义平, 柯爱英 (2019) 乐清湾主要游泳动物空间生态位及其分 化. 应用生态学报, 30, 3911-3920.]

Zhao SL, Xu HX, Zhong JS, Chen J (2016) Zhejiang Marine Ichthyology. Zhejiang Science and Technology Press, Hangzhou. (in Chinese) [赵盛龙, 徐汉祥, 钟俊生, 陈健 (2016) 浙江海洋鱼类志. 浙江科学技术出版社, 杭州.]

Zhao YQ, Zeng JN, Gao AG, Chen QZ, Liao YB, Shou L (2009) Community pattern and diversity of macrozoobenthos in an intertidal flat, Jiaojiang Estuary. Biodiversity Science, 17, 303-309. (in Chinese with English abstract) [赵永强, 曾江 宁, 高爱根, 陈全震, 廖一波, 寿鹿 (2009) 椒江口滩涂 大型底栖动物群落格局与多样性. 生物多样性, 17 , 303-309.]

Zhuang P, Luo G, Zhang T, Zhang LZ, Liu J, Feng GP, Hou JL (2010) Food comparison among juvenile Acipen sersinensis and other six economic fishes in the Yangtze estuary. Acta Ecologica Sinica, 30, 5544-5554. (in Chinese with English abstract) [庄平, 罗刚, 张涛, 章龙珍, 刘健, 冯广朋, 侯 俊利 (2010) 长江口水域中华鲟幼鱼与6种主要经济鱼类 的食性及食物竞争. 生态学报, 30, 5544-5554.]

\section{(责任编委：高天翔 责任编辑：问文杰)}

\section{附录 Supplementary Material}

附录1 浙江中南部海域主要游泳动物功能群物种组成

Appendix 1 Species composition of main nekton functional groups in the coastal waters of south-central Zhejiang Province http://www.biodiversity-science.net/fileup/PDF/2019281-1.pdf 